\title{
Planting Method and Nutrient Management in Teff (Eragrostis tef)-A Review
}

\author{
P. Ashoka ${ }^{1 *}$, N. H. Sunitha ${ }^{2}$ and Mahantesh B. Nagangoudar ${ }^{3}$ \\ ${ }^{1}$ ICAR- KVK, Hanumanamatti University of Agricultural Sciences, Dharwad, India \\ ${ }^{2}$ Department of Home Science, Agricultural Extension Education Centre, \\ Huvinahadagali, India \\ ${ }^{3}$ Department of Agronomy, University of Agricultural Sciences, Dharwad, India
}

*Corresponding author

\section{A B S T R A C T}

\section{Keywords}

teff, nutrition, row planting, fertilizers

Article Info

Accepted:

15 December 2019

Available Online:

20 January 2020
Teff (Eragrostis tef) grass is a minor millet belonging to grass family Poaceae. Being a minor-millet it can withstand adverse conditions of soil and climatic factors. Ethiopia is the major teff grass producing country, a staple food for most of the population of the country. Today's world is more concerned about healthy life which depends on consumption of nutritionally rich food products. Teff is nutritionally rich millet as compared to other cereals and is gluten free, can be substituted for wheat which causes celiac disease due to gluten protein. It is cultivated on marginal soils under traditional practices, which are the major causes for low yields of teff crop. Agronomic practices mainly planting method and nutrient management play an important role in increasing teff yields. Research studies have shown that row planting is advantageous over broadcasting (conventional method) of seeds as it ensures optimum plant population and well crop management. Recent trends in nutrient management are mostly depend only on chemical fertilizers, that to sole applications, this is need to be tackled by use of blended fertilizers or combination of organic and inorganic fertilizers for nutrient supply so as obtain maximum yield.

\section{Introduction}

Teff (Eragrostis teff (Z.) Trotter) is a cereal crop (nutri-millet) belonging to Poaceae family, extensively cultivated in Ethiopia, where the crop is known to have originated (21). In Ethiopia, it is grown on 2.8 million hectares $(24 \%$ of the total cultivated land) annually and contributes $17.57 \%$ of the gross grain production of all grain crops, with a national productivity of $15.75 \mathrm{q} \mathrm{ha}^{-1}$. Over 6.5 million farmers grow teff, which is a major staple food of Ethiopians (greater than 50 million)and contributes to the national food 
security $(10,17)$. Though there are many types in teff grass predominantly white seeded and brown seeded teff are mostly cultivated around the world. In Ethiopia white teff is more preferred over the brown teff. Teff is a highly versatile crop with greater adaptation to different agro-ecologies, and reasonable resilience to both drought and waterlogged environments (2). Being a rainfed crop it is mainly cultivated in the rainy season.

It grows best with an annual rainfall of 750$850 \mathrm{~mm}$ (sufficient for minor millets to complete their life cycle) and with a temperature range of $25-35^{\circ} \mathrm{C}$. The length of growing period ranges from 60 to 180 days with an optimum of 90 to 130 days (11).

\section{Importance}

Teff (Eragrostis teff) is an emerging annual cereal crop. Because of high nutritional quality and hardiness coupled with low water requirement, teff is preferred by the small farmers in rainfed enviornments. Teff is also a strategic crop with high potential to enhance commercialization of smallholder agriculture and improve food security in Ethiopia. Shorter duration of the crop makes it the most suitable crop for multiple cropping systems such as double and relay cropping (18). Compared to other cereals, teff has few insect pests and disease problems in the field (18). Therefore, it is a healthy, reliable and a low risk crop. Teff is the staple food of Ethopians, mainly consumed in the form of "Ingera- flat bread". It is also used for making "porridge" and local alcoholic beverages like "tella" and "katikala" (18). Grains can be stored for many years and fetches higher price as compared to other annual cereals. Teff is the most preferred cereal among better-off households due to nutritional value and cultural preference and it is nutritionally rich with9.4-13.3\% protein (with an excellent balance in essential amino acids, glutamic and aspartic acids being the major), $73 \%$ starch present in whole kernel (stored endosperm section of the grain; (8), 2.6-3.0 \% ash and 2.0-3.1\% lipid $(8,13)$, with rich source of $\mathrm{Fe}, \mathrm{Ca}, \mathrm{Zn}, \mathrm{Mg}$ than other cereal grains $(1,12)$. Teff straw is preferred by the cattles over other cereal crop straw (18). Tef straw is also used for construction purpose, i.e. for reinforcing mud for plastering walls of houses and other household items.

\section{Major constraints in production}

Teff is considered as an orphan (or understudied) crop and its yield is one of the lowest (barely at $15.75 \mathrm{q} \mathrm{ha}^{-1}$ ) compared to other major world cereals. Studies showed that seed and inputs, agronomic practices, harvesting time, trade and marketing are important constraints in teff production (6). In order to increase teff production and productivity, recommended production technologies mainly method of planting and chemical fertilizer have been developed and disseminated to the smallholder farmers in the major teff growing areas over the last several decades.

\section{Method of planting}

Method of planting is the most important operation, among package of practices as it ensures a proper plant population and its establishment. Three methods of planting are in practice viz., broadcasting (traditional), row planting (modern concept) and transplanting (recent trend). The traditional sowing method (broadcasting) used for teff is considered as one of the main reasons why teff yields are low in Ethiopia. Research on improving sowing technologies in teff production had greater attention on row planting. Stochastic production frontier model was used to analyze the teff productivity under both row planting and broadcasting methods. He concluded that a technical efficiency of $80.4 \%$ and $43.8 \%$ across row planting and broadcasting methods 
By adapting row planting, farmers experienced an increase in teff yield in the first year of implementation, but there was also a substantial increase in labor input requirements. A cost-benefit analysis shows that the increase in teff yield outweighs the cost of the extra labor in the first year of adoption when yields increase by 8 percent or more(20). The additional cost of cultivation involved in high labour requirement in row planting and less information known about the new technology did not hinder the farmers in adopting row planting over broadcasting. This may be due to the lesser amount of seed rates, easy mechanization in crop management and lesser competition resulting in higher yields (24). The results of STI (System of Teff Intensification) experiment through transplanting was better than broadcasting, with a fourfold increase in yield under transplanting $(3,400-5,100 \mathrm{~kg} / \mathrm{ha})$ as compared to broadcasting (500 -1,200 kg/ha), there was also a very positive response in the transplanted teff to pelleting the seeds with zinc containing fertilizer than in the broadcasted plots(7). The reasons for higher yield in transplanting compared to other planting methods may be attributed to optimum plant population, increased tillering capacity of the plant, a greater number of productive tillers and higher number of seeds per panicle (7).

\section{Nutrient management}

Decline in soil fertility is the major constraint to agricultural production and food security in farming systems. Farmers have very limited capacity to invest in fertilizers or soil conservation measures. As a result, yields are low and many farmers are forced to put fallow and marginal lands into production to meet their food needs (19). Though organic and inorganic fertilizers have their own advantages, still their individual application is ineffective under certain circumstances.
Therefore, new farming systems have been devised based on integrated soil fertility management (ISFM), which make use of organic fertilizers (farmyard manure and composts) integrated with inorganic fertilizer use. The economic analysis also depicted that applying the balanced nutrients with proper proportion of $\mathrm{N}$ and $\mathrm{P}$ could give the highest marginal rate of return, application of $64 \mathrm{~kg} \mathrm{~N}$ $+30 \mathrm{~kg} \mathrm{P}+25 \mathrm{~kg} \mathrm{~K}+13 \mathrm{~kg} \mathrm{~S}+2.4 \mathrm{~kg} \mathrm{Zn+1}$ $\mathrm{kg} \mathrm{Bha}{ }^{-1}$ is recommended for production of teff(15). The conclusions of Habte and Boke (2017) also supports the above statement i.e. teff responds well to the blended fertilizers (150 kg NPS +34.5 $\mathrm{kg} \mathrm{N} \mathrm{ha}{ }^{-1}$ ) than sole applications. Teff responds well to the urea than any other form of $\mathrm{N}$ fertilizers. Studies shows that $\%$ fertilizer $\mathrm{N}$ use efficiency was higher from urea (49\%) application than by application of ammonium sulphate(34 \%), while the $\% \mathrm{~N}$ derived ff rom fertilizers was higher in Nitisols as compared to vertisols (61.3 and $27.8 \%$ respectively (4). Highest net benefit was obtained applying $67 \%$ of the recommended rates of $\mathrm{N}$ and $\mathrm{P}$ as inorganic fertilizer and $33 \%$ as organic fertilizer based on $\mathrm{N}$ equivalence (14).

Teff (Eragrostis teff) is an emerging annual cereal crop. Because of its high nutritional quality and hardiness, the crop can withstand adverse climatic conditions. The low water requirement of the crop has enhanced the scope of teff with small farmers in low rainfall environments. Planting method plays an important role in ensuring the optimum plant population, proper crop establishment and in turn higher yields. Many of the scientists have experimentally proved that row planting (line sowing) is better than broadcasting.

There is less information known about transplanting of teff, but if studied can definitely result in significantly higher yields. Being a rainfed crop, teff grass requires low external nutrient supply and cultivated under 
marginal soils. Since there is increasing demand for the food, increased yield can be obtained from applying external nutrients to enhance crop growth and yield. Studies have revealed that application of blended fertilizers can enhance the yield potential of the crop as compared to application of individual nutrients. Integration of organic and inorganic components as nutrient supplying components will supply all the nutrients (micro and macro) rather than aplying only external fertilizers as it is obvious from the research studies.

Table.1 Mineral content of teff grain compared to other cereals, mg/100g

\begin{tabular}{|c|c|c|c|c|c|c|c|}
\hline Minerals & teff & Red teff & $\begin{array}{c}\text { Mixed } \\
\text { teff }\end{array}$ & $\begin{array}{c}\text { White } \\
\text { Maize }\end{array}$ & Sorghum & Wheat & Rice \\
\hline Iron & $9.5-37.7$ & $11.6->150$ & $11.5->150$ & $3.6-4.8$ & $3.5-4.1$ & 3.7 & 1.5 \\
\hline Zinc & $2.4-6.8$ & $2.3-6.7$ & $3.8-3.9$ & $2.6-4.6$ & $1.4-1.7$ & 1.7 & 2.2 \\
\hline Calcium & $17-124$ & $18-178$ & $78.8-147$ & 16 & $5.0-5.8$ & $15.2-39.5$ & 23 \\
\hline Copper & $2.5-5.3$ & $1.1-3.6$ & 1.6 & 1.3 & 0.41 & 0.23 & 0.16 \\
\hline
\end{tabular}

Sources: Abebe et al. 2007; Baye et al. 2014; Gebremariam et al. 2012; Kebede 2009; USDA/ARS 2014

Fig.1 Teff grass, seeds and its consumable products

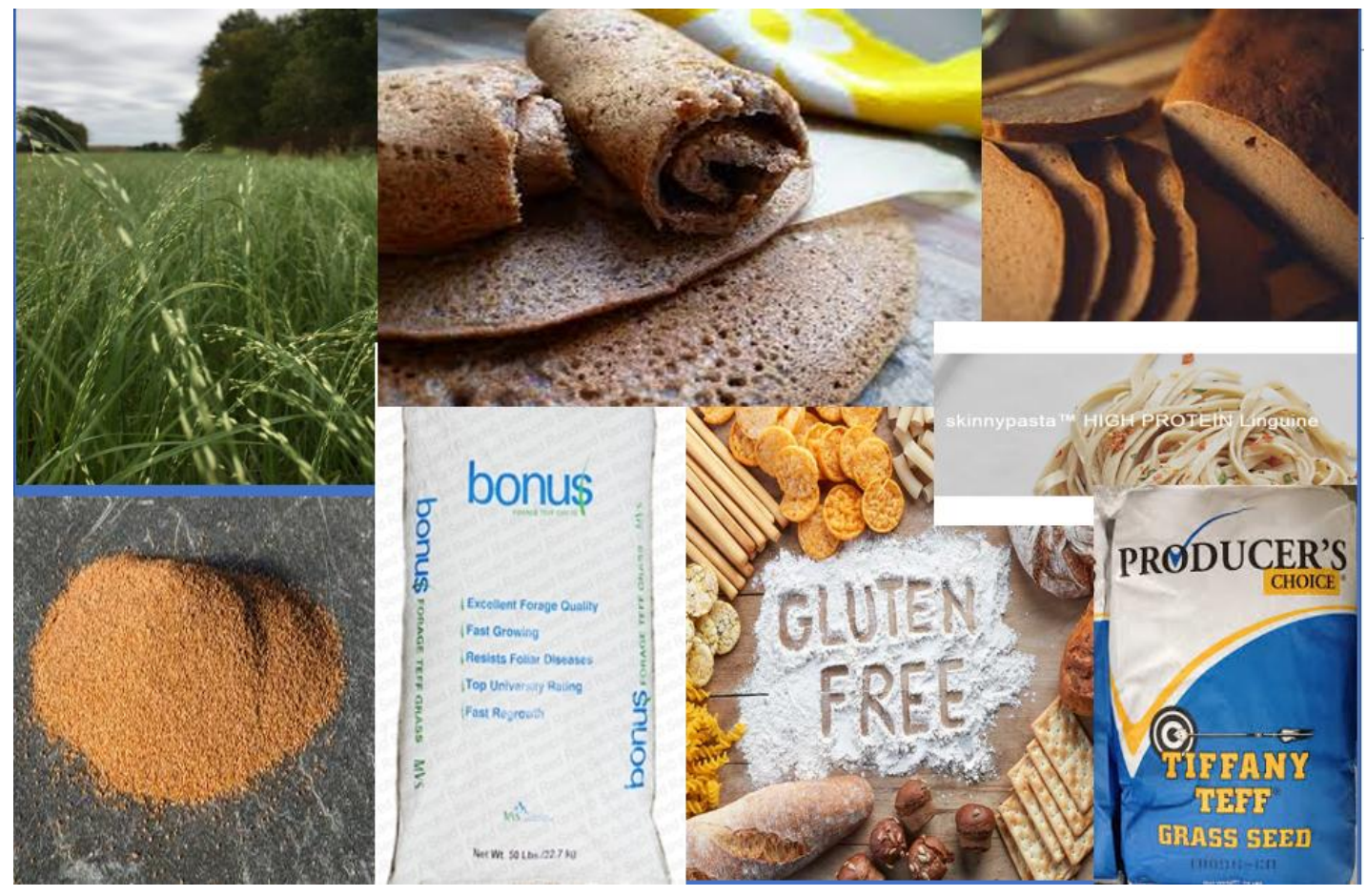


Fig.2 Conceptual frame work on the adoption of Teff row planting and yield amount (5) respectively could be achieved (24)

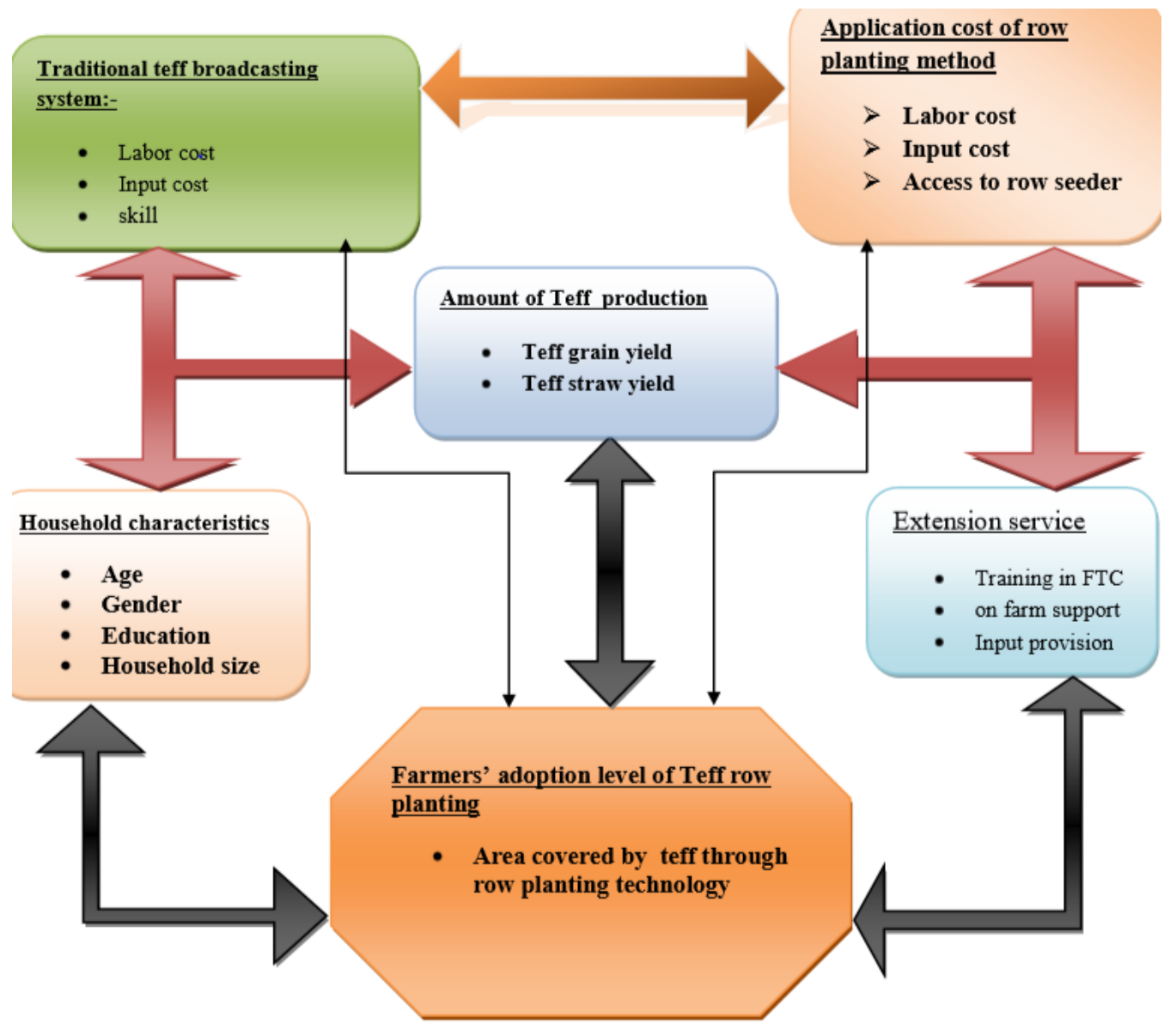

\section{References}

Abebe, Y., Alemtsehay, B., Michael, H., Barbara, K., Karl, J. S., \& Rosalind, B. (2007). Phytate, Zinc, Iron and Calcium content of selected raw and prepared foods consumed in rural sidama, southern Ethiopia, and implications for bioavailability. Journal of Food Composition and Analysis, 20, 161-168.

Assefa, K., Yu, J. K., Zeid, M., Belay, G., Tefera, H. and Sorrells, M. E., 2010, Breeding tef (Eragrostis teff (Z.) Trotter): conventional and molecular approaches (review). Plant Breeding.j.1439-0523.

Ayalew, A. and Habte, M., 2017, Use of balanced nutrients for better production of Teff (Eragrostis teff (Zucc.) at Bensa in Southern Ethiopia.J. Resour. Dev. and Manag.,32:46-50.

Balesh, T., Felipe, Z., Jens, A. and Bishal, S., 2005, N fertilisation, soil type and cultivars eff ects on $\mathrm{N}$ use efficiency in tef (Eragrostis tef (Zucc.) Trotter), Nutrient Cycling in Agroecosystems 71: 203-211, DOI 10.1007/s10705-0045083-1. Springer 2005

Behailu Getu Desta, 2014, Assessment of factors affecting farmers' adoption level of row planting technology and yield improvement on the production of Eragrostis Teff (ZUCC.): The case of Minjar Shenkora Woreda, Amhara 
Region, Ethiopia, M. Sc. Thesis, Addis Ababa University, Ethiopia.

Bekabil, F., Befekadu, B., Rupert, S. and Tareke, B., 2011, Strengthing the teffvalue chain in Ethiopia. Agricultural Transformation Agency, Ethiopia.

Berhe, T., and Zena, N., 2009, Results in a trial of System of Teff Intensification (STI) at DebreZeit, Ethiopia.

Bultosa, G. (2007). Physicochemical characteristics of grain and flour in 13 Tef (Eragrostis tef (Zucc.) Trotter) Grain Varieties. Journal of Applied Sciences Research, 3, 2042-2050.

Bultosa, G., \& Taylor, J. R. N. (2004). Teff. In C. Wrigley, H. Corke, \& C. Walker (Eds.), Encyclopedia of Grain Science (pp. 20-36). Oxford, London: Elsevier.

CSA (Central Statistical Agency), 2015, Agricultural Sample Survey 2014/2015: Volume I, Report on area and production of major crops (Private Peasant Holdings, Meher Season). Stat.Bull., Addis Ababa, Ethiopia.

Deckers, J., Spaargaren, O. and Nachtergaele, F., 2001, Vertisols: Genesis, properties and soil cape management for suistanable development, FAO, Rome, Italiy.

Demeke, M. and Marcantonio, F., 2013, Analysis of incentives and disincentives for teffin Ethiopia. Technical notes series, MAFAP, FAO, Rome.

Gebremariam, M. M., Martin, Z., \& Thomas, B. (2012). Teff (Eragrostis tef) as a raw material for malting, brewing and manufacturing of gluten-free foods and beverages: A review. J. Food Sci. and Tech., 51, 2881-2895.

Habte, M. and Boke, S., 2017, Influence of balanced nutrients on growth performance and yield of Teff (Eragrostistef(Zucc.)) in the midland of Bensa, Southern Ethiopia. J. Sci. and Innov. Res., 6(3):101-103.

Habte, W., Smith, Jo, U. and Shiferaw, B. A.,
2018, Integrated soil fertility management for sustainable teff (Eragrostistef) production in Halaba, Southern Ethiopia. Cogent Food and Agric., 4: 1519008.

Hagos, W., 2014, The determinants of technical efficiency of farmers in Teff, Maize and Sorghum production: Empirical Evidence from Central Zone of Tigray Region, Ethiopian J. Econ., Vol. XXIII No 2.

Kebebew, A., Sherif, A., Getachew, B., Gizaw, M., Hailu, T. and Mark, E. S., 2011, Quncho: the first popular teffvariety in Ethiopia, Int.J. Agri. Sustain., 9(1): 25-34.

Ketema, S., 1997, Tef (Eragrostistef (Z.) Trotter); Promoting the conservation and use of underutilized and neglected crops 12. Institute of Plant Genetics and Crop Plant

Research, Gatersleben/International Plant Genetic Resources Institute, Rome, Italy ISBN 92-9043-304-3.

Tilahum, D., 2004, Soil fertility status with emphasis on some micronutrients in vegetable growing areas of Kolfe, Addis Ababa, Ethiopia. M. Sc. (Agri.) Thesis, Alameya University, Ethiopia.

Vandercasteelen, J., Dereje, M., Minten, B. and Taffesse, A., 2014, Perceptions, impacts and rewards of row planting of teff.LICOS Discussion Paper Series.350. 10.2139/ssrn.2530422.

Vavilov, N. I., 1951, The Origin, Variation, Immunity and Breeding of Cultivated Plants.Translated from the Russian by K. Starrchester. Ronald Press, NewYork, 37-38.

WWW.newindianexpress.com www.thehindubusinessline.com

Zuber, O. M., 2018, Comparative technical efficiency of teff production in row planting and broadcasting methods, Ethioopia, J. Appl. Agri. Econ. and Policy Anal. 1(1);8-14. 
How to cite this article:

Ashoka, P., N. H. Sunitha and Mahantesh B. Nagangoudar. 2020. Planting Method and Nutrient Management in Teff (Eragrostis tef)-A Review. Int.J.Curr.Microbiol.App.Sci. 9(01): 145-151. doi: https://doi.org/10.20546/ijcmas.2020.901.016 